\title{
Egyptian and Other Elements in the Fifth- Century Mosaics of S. Maria Maggiore
}

\begin{abstract}
The point of departure for this article is the mosaic with Nilotic motifs that runs along the bottom of the apse of S. Maria Maggiore in Rome. The mosaic is a work of Iacopo Torriti dating to 1296. There has been a great deal of discussion, however, whether he invented the motifs or whether he copied them from the fifth-century apse (or even included parts of the original). It is here suggested that Torriti used motifs which were originally present in the fifth-century apse, and that they, together with other motifs relating to Egypt in the still preserved fifth-century mosaic panels, had a symbolism well suited to the ideas about Mary and the Incarnation that were prevalent in Rome in the fifth century.
\end{abstract}

\section{The Nilotic scene in the apse}

With the expression "Egyptian elements", I simply mean scenes set in Egypt. I shall start with the Nilotic scene that runs along the bottom of the apse of the basilica of S. Maria Maggiore. (Fig. 1). This scene does not belong to the fifth-century context, but is a work of Iacopo Torriti dating to 1296. A few years earlier, in 1291, Torriti had created a related scene in the apse of S. Giovanni in Laterano. ${ }^{1}$

First, some preliminary remarks shall be devoted to Nilotic scenes in general. As the name indicates, they involve the river Nile. In ancient art, rivers are generally represented as male figures reclining on an urn from which water flows. The more important rivers also have one or more attributes that show what river is meant in each specific case. The attribute of the Nile is generally a cornucopia, a horn of plenty, an allusion to the richness provided by the river, often coupled with a real or mythical creature connected with Egypt such as a crocodile or a sphinx. ${ }^{2}$ But the Nile is also represented in a more realistic manner, as a river teeming with life. Typical of Nilotic scenes are wooden palisades in the water giving shelter to ducks and other aquatic birds; fishes and fishermen; putti or erotes disporting themselves in various ways; and flora and fauna char-

1. Tomei 1990 a, 77-125; Tomei 1990 b.

2. EAA V (1963), 489-493 (text: Bonacasa, F. and 
acteristic of the Nile such as lotus flowers, ibises, hippopotami and crocodiles. The latter are sometimes shown being hunted by pygmies. Often the Nile Delta with the city of Alexandria is alluded to. The famous Pharos may be seen in the background, as well as temples and gods. ${ }^{3}$

A number of late-antique monuments show a Nilotic scene dominated by a nude woman and her consort together with a smaller, fully clothed woman. As Joseph Polzer has shown, the couple are probably Isis and Osiris, while the smaller woman is a devotee of the goddess. ${ }^{4}$ As a fertility goddess Isis was connected with the Nile in the Roman period. Generally the river is either shown as a traditional river god or as an expanse of water teeming with living creatures. Occasionally both are shown together, as in a fifth-century mosaic from Beth Shean where the river god is shown in the upper part of the panel, while the rest is filled with Nilotic motifs. ${ }^{5}$

The number of Egyptian elements in Nilotic scenes varies considerably. Some are very rich, while others limit themselves to a few motifs, generally aquatic fowl behind fences and putti or fishermen. The rivers running at the bottom of the apses in S. Giovanni in Laterano and S. Maria Maggiore contain enough elements to be called Nilotic, though the river in S. Giovanni is labelled Jordan. The choice of the river Jordan is natural enough in a church dedicated to the Baptist, but it is highly unusual, not to say unique, to represent the river in such a way. In Roman apses the Jordan is normally shown as a neutral stretch of water, as can be seen in SS. Cosma e Damiano and S. Prassede. ${ }^{6}$ It therefore needed to be accompanied with an inscription specifying its name, as there is no external element to distinguish it.

The river scenes in S. Giovanni and S. Maria Maggiore have not been a focus of scholarly attention, but they have been the subject of debate. The various opinions may be summarized thus:

1) Both mosaics are faithful copies of late-antique predecessors that originally decorated the apses of their respective churches. Some scholars have gone as far as to suppose that parts of the S. Maria Maggiore mosaic are late-antique fragments that were salvaged by Torriti and reused by him in his new apse. ${ }^{7}$

3. For Nilotic scenes in Roman art see Faucher 1965; Ibrahim, Scranton and Brill 1976, 121163; de Vos 1980; Meyboom 1995, especially 96107; Tammisto 1997, 45-70; Rauch 1999, 251256.

4. Polzer 1986.

5. Alföldi-Rosenbaum 1971, 151, pl. LVIII,2; Alföldi-Rosenbaum and Ward-Perkins 1980, 46, pl. 86,3; Ovadiah 1987, 35-36, pl. XXXII,1-2; LIMC VI,1, 720-721 (text: Jentell, M.-O.), VI,2, 425,7 .
6. Oakeshott 1967, colour pl. XIII, fig. 24; Matthiae 1967, figs. 78, 176; Matthiae and Andaloro 1987, figs. 45, 131.

7. Ainalov 1961, 195; Oakeshott 1967, 94-96, 312; Matthiae 1967, 355; Verdier 1980, 157; Matthiae and Gandolfo 1988, 198-199. Others (Cecchelli 1956, 251-252; Bertelli 1997, 55-56) have remarked that the Nilotic scene in S. Maria Maggiore may well have been a borrowing from the old apse mosaic, without pronouncing themselves on S. Giovanni. 
2) Neither of them refers to earlier versions. Both are free inventions by Torriti, who based himself on Roman models. ${ }^{8}$

3) One mosaic copies a late-antique version present in the original apse. Generally this mosaic is thought to be the one in S. Giovanni, whereas the S. Maria Maggiore mosaic is regarded as a new feature introduced by Torriti. According to this view the river in both instances is the Jordan, though that of S. Maria Maggiore is unnamed. ${ }^{9}$

With regard to the first hypothesis, the idea that Torriti reused parts of the original mosaics has been abandoned by present-day scholars. He did reuse the bust of Christ in the apse of S. Giovanni, mounting it on a slab of travertine that was affixed to the background by means of clamps. ${ }^{10}$ However, this was a special case because the bust was considered to be miraculous, and it comprised a relatively small area, the travertine slab measuring only $105 \times 75 \mathrm{~cm}$. There is no evidence that Torriti took down and reused larger areas of the mosaics that were to be replaced. It would probably have resulted in disaster anyway, like the nineteenth-century experiment with the apse mosaic of S. Giovanni.

There can be no doubt, therefore, that the river scenes in S. Maria Maggiore and S. Giovanni were made by Torriti and his workshop. That does not exclude the idea that they reproduced similar scenes in the late-antique apses. The twelfth-century description by Giovanni Diacono of the apse in S. Maria Maggiore mentions fish, flowers, animals and birds. His description is difficult to reconcile with the idea of a floor mosaic, which has sometimes been proposed. ${ }^{11}$ This litterary evidence strongly suggests that the original fifth-century apse was decorated with a Nilotic scene.

With regard to S. Giovanni, there is no evidence for such a scene in the lateantique apse. As remarked above, the river Jordan is always rendered as an anonymous stretch of water in earlier Roman apse mosaics. Furthermore, when comparing the Nilotic scenes in the two churches, it becomes clear that, contrary to what has been maintained by many scholars, that of $\mathrm{S}$. Maria Maggiore is much closer to late-antique models than that of S. Giovanni. This is especially clear when one compares Torriti's treatment of the same motif in the two churches, such as the river gods and the figure of an erote sailing on an amphora.

8. Brenk 1975, 3-4; Wilpert and Schumacher 1967, 76-78; Schwarz 1989, 124-125; Tomei 1990 a, 109-110; Tomei 1990 b, 94.

9. Menna 1991, 235, n. 4. According to her, the river is in both cases the Jordan. Cecchelli 156, 251, also believes that the river in S. Maria Maggiore is the Jordan.

10. Tomei 1990, fig. 102.

11. Wellen 1961, 124, and Brenk 1975, 3, thought that Giovanni Diacono's description refers to a floor mosaic, but as has been pointed out by Verdier 1980, 157 with n.13, Bertelli 1995, 55, and Bisconti 2000, 17-18, the mosaic is likely to have been on the wall. Giovanni describes it from the point of view of the congregation, who could not have seen a floor mosaic behind the altar. Bertelli thinks that Giovanni's description refers to the peopled acanthus scrolls in the apse, but only in the Nilotic scene does one find fishes, flowers, animals and birds together. 


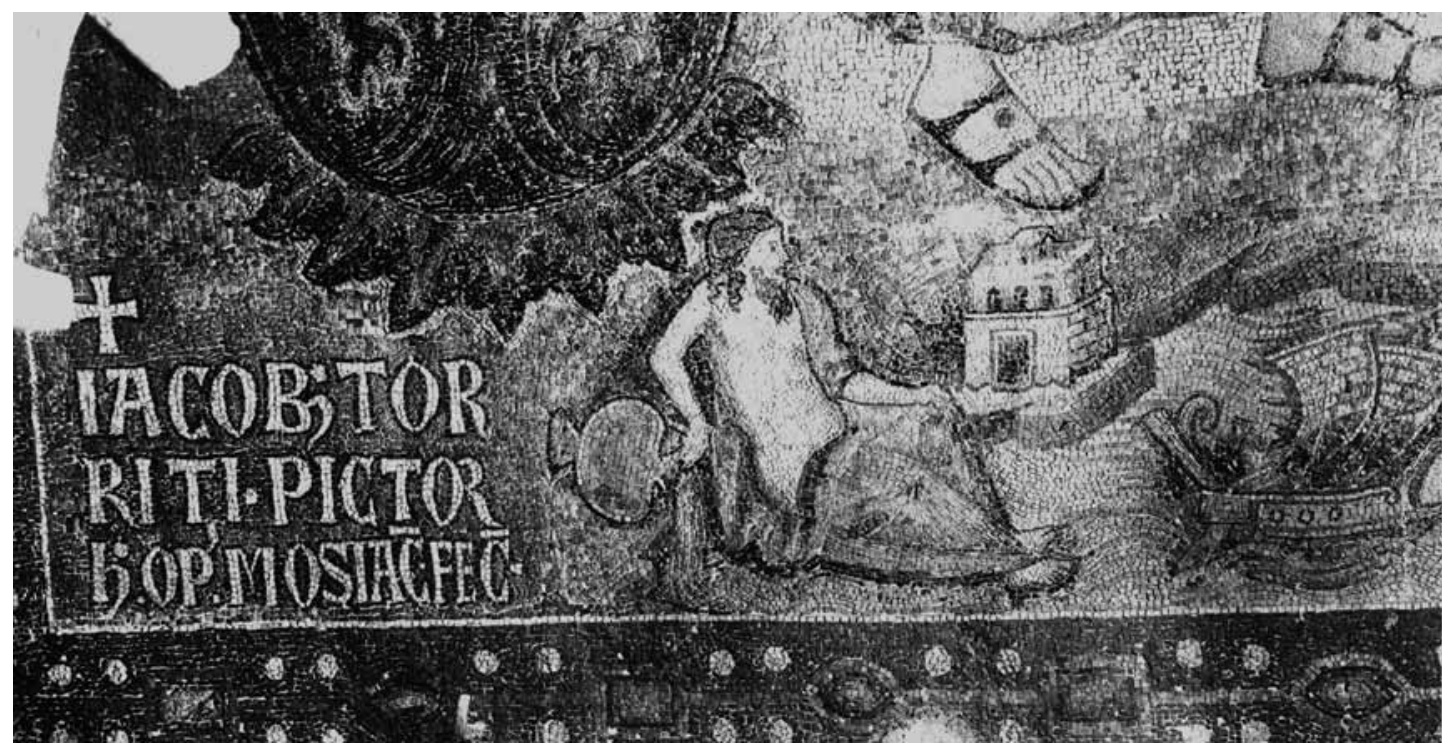

FIg. 1 - S. Maria Maggiore, apse: The Nile (Photo: Musei Vaticani neg. XXX.33.23).

Like the above-mentioned mosaic from Beth-Shean, that of S. Maria Maggiore shows the Nile both as a river and a personification in human form. The scene starts on the left with a personified representation of the Nile, who is seen reclining on the riverbank in the normal manner of ancient river gods, the water flowing from his urn (Fig. 1). The scene is set in the Nile Delta, as indicated by a lighthouse, no doubt the famous Pharos of Alexandria, with a ship leaving the harbour. If the modern restoration on the right of the mosaic reproduces the original version, the figure of the Nile was duplicated. In S. Giovanni he is immersed in the water, urn and all, and instead of the dignified mature man who represents the Nile in ancient art, we have a putto (Fig. 2). Both these features are anomalous. Furthermore, two more river gods have been introduced, Jor and Dan. They take the place of the river gods in S. Maria Maggiore, with water flowing from their urns. Jor and Dan allude to the sources of the river Jordan according to a false etymology which was popular in the middle ages. ${ }^{12}$ They are shown as nude youths. They do not recline on their urns, which are shaped like amphorae, but carry them on their shoulders. This type of river god is not ancient, but medieval. It derives from representations of the constellation Aquarius. ${ }^{13}$

The erote sailing on an amphora is found in Nilotic scenes of the Roman period. He is standing on the vessel, having tied the sail to one of its handles. The upper corners of the sail are grasped by his outstretched hands. This motif is probably a playful allusion to Isis Pelagia or Euploia, the protectress of sailors, 


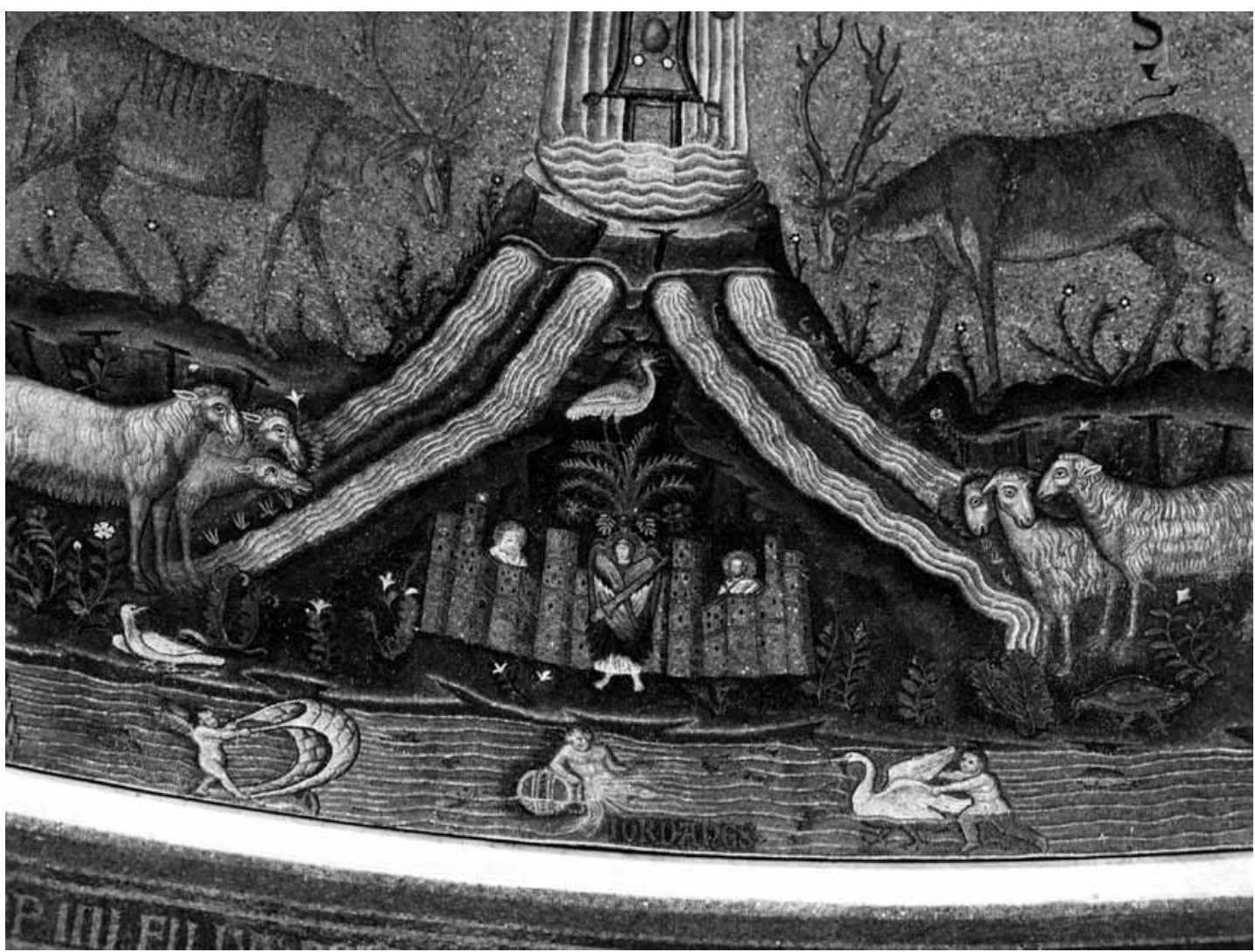

FIG. 2 - S. Giovanni in Laterano, apse: The River Jordan and erote on amphora (Photo: I.C.C.D. E 61789).

who is shown standing on a ship or raft in a similar manner, using her cloak as sail. ${ }^{14}$ Erotes (or pygmies) standing on an amphora are comparatively rare. One example occurs in the well known Nilotic mosaic from the Villa del Nilo in Leptis Magna (Fig. 3), but the motif was also known in Italy, as testified by a stucco fragment in the Museo Nazionale in Naples and three mosaics from Lucera, Collemancio and Rome respectively. ${ }^{15}$ The stucco fragment in Naples and the mosaic from Lucera show isolated erotes on amphorae, but in the other two mosaics the Nilotic context is confirmed by the presence of crocodiles and hippopotami. The motif in S. Maria Maggiore is perfectly reproduced (Fig. 4). The amphora is of a different, more elongated shape than the one in the Roman mosaics, but it is of an ancient type, and the sail is fastened to one of its handles.

14. LIMC V,1, 782-784 (text: Tran Tam Tinh), V,2, 519.

15. Guidi 1933, 16-17, figs. 6, 8, 9; Aurigemma 1960, 48, pls. 87-88; Squarciopino 1966, $127-$
128, fig. 98; Blake 1936, 123-124, pl. 33, fig. 1; Aurigemma 1958, 27-28, no. 47, pls. X, XI, La Regina 1998, 192. 


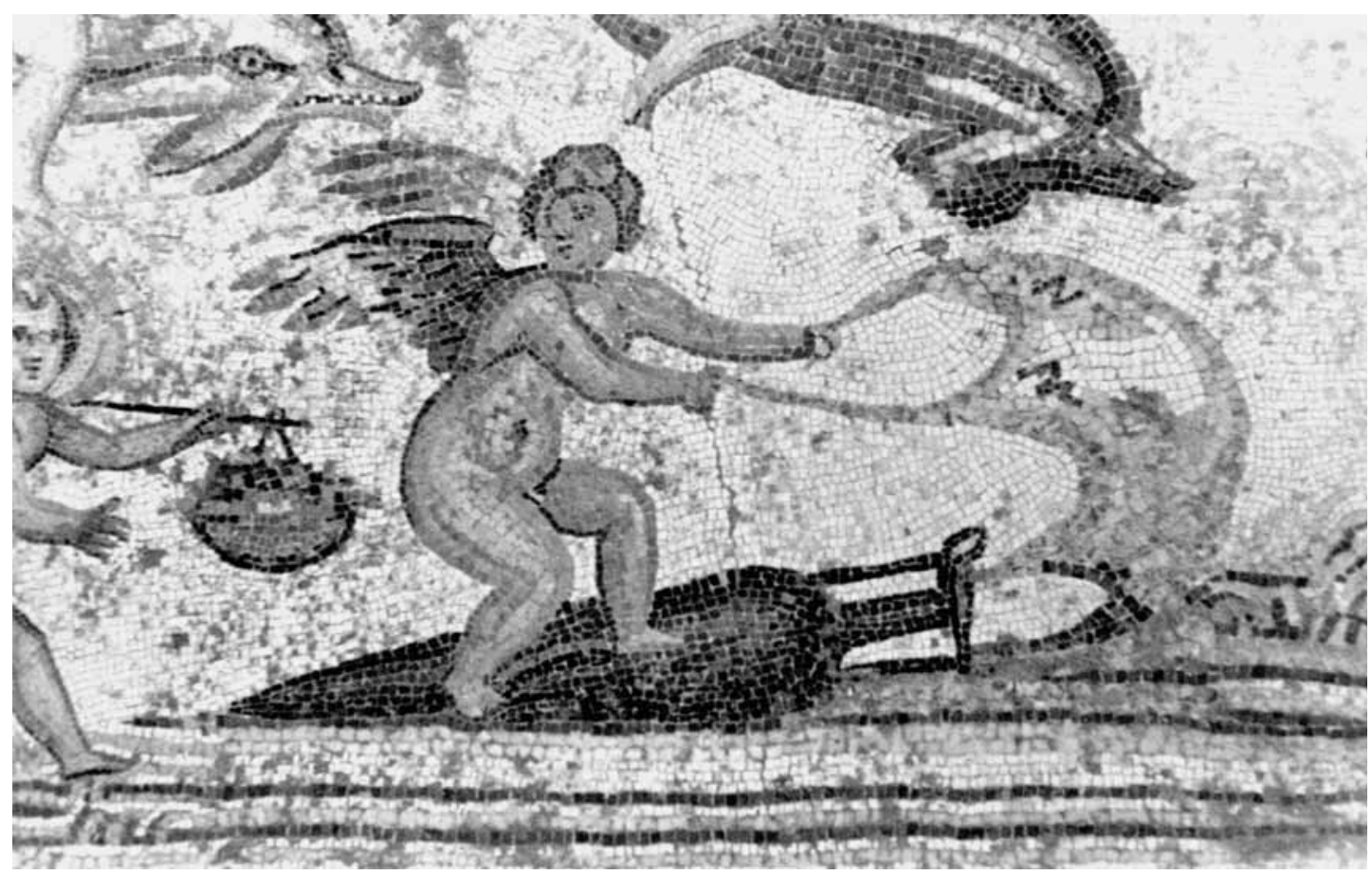

FIg. 3 - Erote on amphora, detail of a mosaic from Leptis Magna (Photo: author).

The erote is standing firmly on the vessel. In S. Giovanni the motif is misunderstood: the amphora is shapeless; it has no real connection with the sail; and the erote is barely touching it with one foot (Fig. 2). The only way to explain the difference between the two is that Torriti had better models on which to draw when he made the S. Maria Maggiore mosaics, and these models he is likely to have found in the basilica itself. If, as has been maintained by some authors, he designed both mosaics from his own imagination using ancient models which he found in various contexts, these models would have been copied with an equal degree of correctness in both cases. Here, however, the earlier mosaic, which ought to have been the model, is more incorrect than its supposed copy.

My guess is that Torriti got the idea of a 'peopled' Jordan from the Nilotic mosaic in S. Maria Maggiore. He saw the motifs from below. The old mosaic could have been in a bad state of preservation, and Torriti may have had difficulties in making out the more unusual motifs such as the erote on the amphora. Since he was not dependent on an older representation in S. Giovanni, he was free to use the ones he wanted from S. Maria Maggiore while adding some motifs of his own such as the figures of Jor and Dan.

In S. Maria Maggiore, evidently, Torriti had been commissioned to include the original Nilotic scene in his new apse composition. For that reason he copied it. To do so he must have had access to it from scaffolding erected in connection 
with its demolition. He would thus have been able to see the figures at close quarters, and also the preparatory drawings, which would have appeared once the tesserae were removed. Thus his models would have conformed to their lateantique prototypes, but sometimes he made mistakes. This is evident in an enigmatic scene below the feet of the left group of angels flanking Christ and his Mother. Here we see a hysterically barking dog with a man who is probably a hunter. He puts his left index finger to his chin in a gesture which is ancient art denotes perplexity or unease, looking towards a monstrous being emerging from the waters (Fig. 5). This creature must have been a crocodile or hippopotamus, probably the latter, since it has ears. ${ }^{16}$ Torriti was familiar with birdlife, erotes and fishermen, but evidently not with such a creature, which fell outside the normal repertory drawn from ancient art.

It is reasonable to see Torriti's reuse of the Nilotic motifs in S. Maria Maggiore in the general context of the classicising revival that is typical of Roman thirteenth-century art. The Nilotic scenes may have had predecessors dating to the early thirteenth century. The apse mosaic in the Constantinian basilica of St. Peter, associated with Innocent III (1198-1216), but completed only under his successor Honorius III (1216-1227), showed small, putto-like figures frolicking in the landscape surrounding Christ flanked by St. Peter and St. Paul. ${ }^{17}$ The mosaic is known only through a sixteenth-century watercolour. Its details are therefore difficult to judge. The scenes with the putti have been called Nilotic by some authors. The four rivers of Paradise were present in the middle of the apse, but no expanse of water could be seen along the sides; its presence is perhaps not to be expected in so cursory a rendering as this watercolour, but one misses the boats and other craft that are so typical of Nilotic scenes. Still, the putti may have been borrowed from such scenes.

In this context, reference should be made to a splendid icon in the Monastery of St. Catherine on Mount Sinai. Datable to the end of the twelfth century, it has on account of its high quality been regarded as a work from Constantinople. The subject of the icon is the Annunciation, but the bottom of the scene is filled with fishes and birdlife in a landscape which is clearly borrowed from the traditional Nilotic repertory. ${ }^{18}$ Do we have Nilotic revivals both in the East and the West at the time around 1200? Two works of art are too few to build a hypothesis on, but the coincidence is worth mentioning.

16. De Rossi, 1899, pl.XXXIX, erroneously reproduced the animal as a wolf, an identification repeated in Wilpert and Schumacher 1976, 77.

17. Waetzoldt 1964, 71, no. 943, fig. 490; Wilpert and Schumacher 1976, 11; Andaloro and Romano 2000, 114-115, figs. 62, 65; Andaloro and Romano 2002, 94-96, fig. 70. Schumacher thought the putto-like figures represent the Sea- sons. This is more likely than a Nilotic scene, as no water is visible. The Seasons, however, would have had the same meaning as a Nilotic scene: the recurring renewal of Nature.

18. Weitzmann 1965, Weitzmann 1978, 92, pl. 27; Maguire 1981, 48-52, fig. 42; Schwarz 1989, 115-116, fig. 14 a-b; Cormack 2000, 154-155, fig. 85 . 
The repetition of a Nilotic scene in the medieval S. Maria Maggiore can be assumed to be a sign of a general antiquarian trend in the thirteenth century. But that does not explain why it was included in the fifth-century basilica. The association between Mary and the Nile may at first appear odd, though we have already seen it in the icon from Mount Sinai. First it should be said that Nilotic scenes in early Christian art are by no means uncommon. There are several examples in floor mosaics in churches, especially from the Eastern Mediterranean. Studies by scholars such as Ernst Kitzinger, Elizabeth Alföldi-Rosenbaum and Henry Maguire have showed that Nilotic scenes are related to marine scenes, which are also present in a number of floor mosaics (indeed, it is sometimes difficult to decide if a scene should be termed Nilotic or simply marine). ${ }^{19}$ Since the Nile was the life-giving water par excellence, ${ }^{20}$ it is only natural that it should stand for water in general, like the sea. In floor mosaics, scenes of this kind represent the watery element; they generally form part of a microcosm inside the walls of the church which represents the macrocosm outside it.

However, if this is the likely meaning of the Nilotic motifs in floor mosaics, this interpretation cannot automatically be transferred to Nilotic scenes in other contexts, where they are placed in more representative parts of the church such as apses or domes. Nilotic scenes are rarely found in these positions (this could of course be attributable to the fact that the majority of early churches do not have their walls preserved, or at any rate not their original mosaics). In Rome, which is the most logical place to search for possible models in connection with a Roman basilica such as S. Maria Maggiore, there were at least two Nilotic (or possibly Nilotic) scenes in Christian buildings. Both were placed in the dome or in proximity to the apse. Both are now lost, but parts of them, at least, were copied before their destruction.

The earliest such Nilotic scene is that of the mausoleum of S. Costanza from the middle of the fourth century. ${ }^{21}$ It ran along the bottom of the dome mosaic. Only a fraction of it was drawn before it was demolished in the eighteenth century, but enough to establish its Nilotic character. The presence of a Nilotic scene in a mausoleum is understandable, since it was a well-known motif in Roman funerary art. The Nile, whose fertilizing mud covered its banks every year, was a natural symbol of renewal, regeneration and a new life. It was therefore well suited in funerary contexts. Devotees of the Egyptian gods might include them, but the Nilotic symbolism could also be used without any wish to establish a special relationship with the gods connected with the river. The more bland Nilotic scenes with a general reference to regeneration and a new

19. Kitzinger 1950; Alföldi-Rosenbaum 1971; Alföldi-Rosenbaum and Ward-Perkins 1980, 45-51; Maguire 1987, 41-55.

20. For examples of the allegorical use of the Nile in Christian texts and images see Maguire 1987,
29, 42-47, 51-52, 82.

21. Stern 1958; Grabar 1968, 137, figs. 331-332; Wilpert and Schumacher 1976, 52-55, pl. 5; Maguire 1981, 50-51, fig. 43; Schwarz 1989, 100, fig. 6 . 
life could without great difficulties be transferred to a Christian setting, provided that they were purged of references to Egyptian religion.

With the second scene we leave the realm of funerary iconography and enter a real church, or rather a small oratory. It was found in 1876 below the so-called Monte della Guistizia during the construction of the Stazione Termini. ${ }^{22}$ In Antiquity this area corresponded to the agger of the Republican city walls, which was gradually covered with buildings as the old walls lost their defensive function. The oratory was installed in a structure from the second century AD, which was accommodated to its new function. De Rossi, who studied it before it was demolished, dated it to the fifth century. The apse of the oratory, which is anonymous (it has been tentatively identified with the small church of S. Agata on the Esquiline), was decorated with frescoes, which were detached from the walls before the building was destroyed, like the other ancient structures in the area which stood in the way of progress, represented by the railway station. However, the frescoes, like many bits and pieces of ancient Rome, "inexplicably" disappeared. De Rossi speaks of them in his publication as "sequestrati". He promised a more exhaustive study of them as soon as they were available, but since this never happened, his preliminary publication is the only evidence we have. The frescoes of the apse of the oratory were divided into an upper and a lower zone. In the upper one Christ was depicted seated, surrounded by the twelve apostles, who were shown standing. In De Rossi's publication they are illustrated as shadowy figures drawn from memory. However, De Rossi vouches for the correctness of the rendering of the lower zone, which was drawn when the frescoes were still in situ. This lower zone shows fishermen of whom some are fishing from boats, whereas others are standing on tiny islands such as are often seen in Nilotic scenes.

This illustration is one of those cases where it is impossible to decide if a scene is Nilotic or marine, simply because it is not detailed enough. It is impossible to determine whether the fishermen are putti or adults, or whether the fresco contained lotus flowers or other typically Nilotic motifs. De Rossi mentions only fishes. Even if the rendering of the larger figures and their relationship to each other is substantially correct, the draughtsman may have left out smaller details and concentrated on the main motif, fishing. Nilotic or not, the scene is probably intended to allude to the apostles as fishers of men, which is reasonable in this context.

With regard to the Nilotic scene in S. Maria Maggiore, it is reasonable to see it in the traditional context of renewal and regeneration. Henry Maguire has opined in his book Art and Eloquence in Byzantium that the renewal of the world brought about by the Incarnation was especially associated in the Eastern Church with the feast of the Annunciation, which heralded this event. ${ }^{23}$ To symbolize the notions of regeneration and renewal metaphors of spring were often used, such as ships leaving the harbour (the sailing season started in spring, having

22. De Rossi 1876; Testini 1963, especially 230-235; Schwarz 1989, 124-125, fig. 20; Bisconti 2000 b,
187, fig. 6 .

23. Maguire 1981, 42-52. 


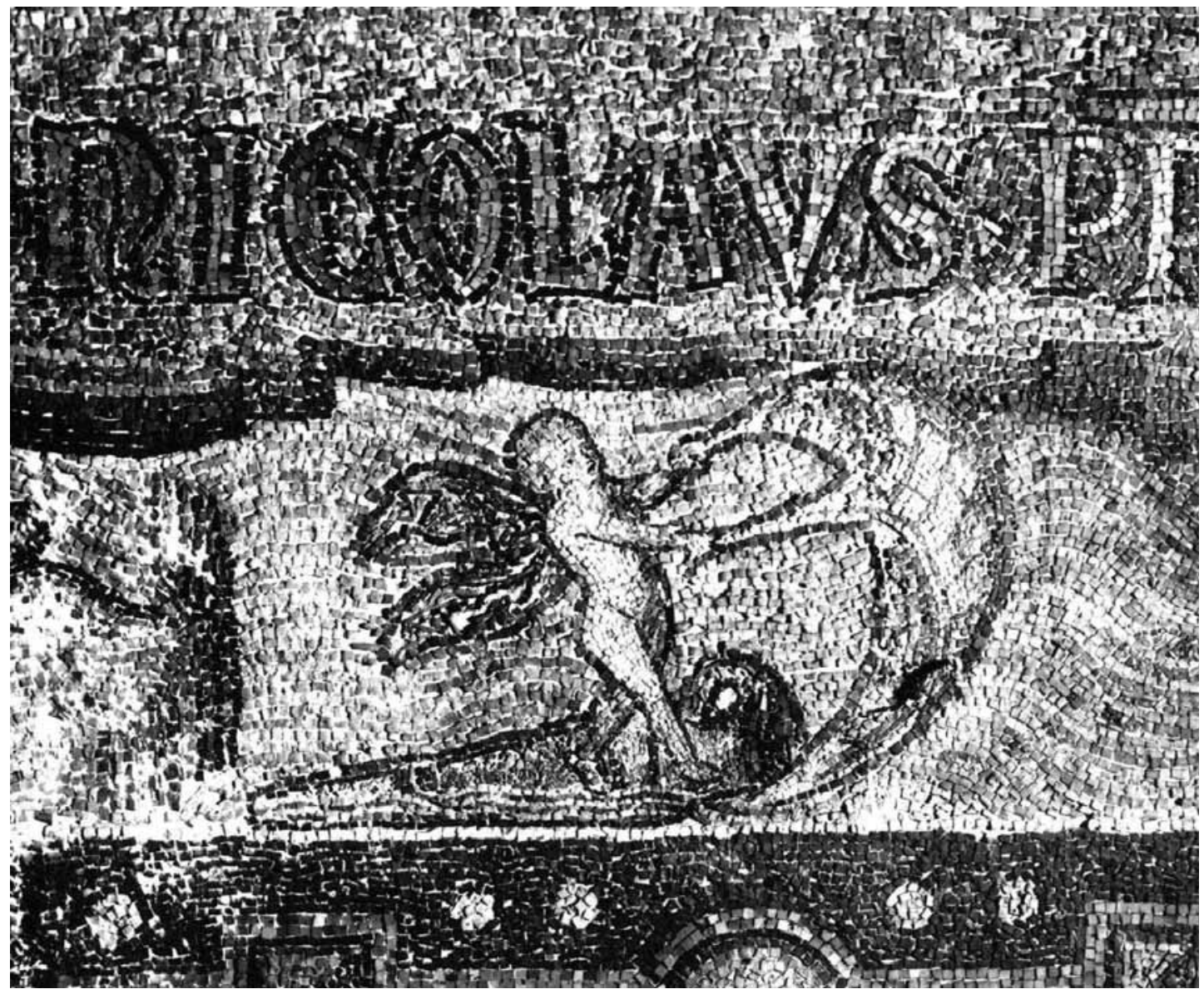

FIG. 4 - S. Maria Maggiore, apse: Erote on amphora. Photo: (Musei Vaticani neg. XV.1.19).

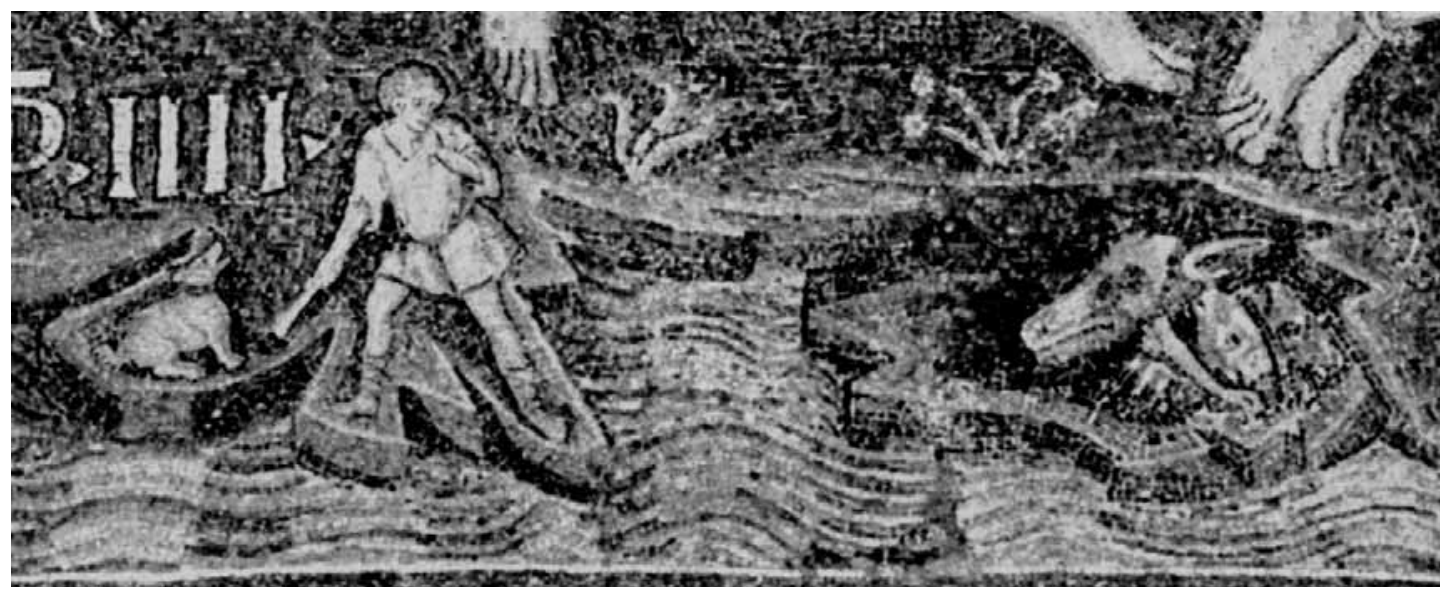

FIG. 5 - S. Maria Maggiore, apse: Hunter and hippopotamus (?) (From Karpp 1956, pl. 171). 
been suspended during the winter), rivers flowing, dolphins leaping, fishes and birds filling the water and air respectively (and, one might add, people taking advantage of this by devoting themselves to fishing, fowling and other hunting activities), vegetation busting forth, and so on. These motifs are found both in literature and the pictorial arts. Many of them recur in Nilotic scenes, and such a scene could replace the more vignette-like allusions to spring, as is shown by the icon from Mount Sinai referred to above.

Maguire's study regards proto-Byzantine and Byzantine examples, but the association between the Incarnation and the idea of renewal and regeneration of nature was recurrent in the West, too, at least in Late Antiquity. The Western authors generally express such ideas much more succinctly, in contrast to the long and complicated ekphraseis of the Byzantines. In a sermon delivered at the other great feast commemorating the Incarnation, the Nativity, Leo the Great (440-461) speaks about how Christ through his incarnation "made in himself the beginning of a new creation, and in the 'form' of his birth started the spiritual life of mankind afresh" (XXVII, 2, the seventh of his Nativity sermons). In his second sermon in the same series he compares the recurring renewal of the Christian mystery contained in the Incarnation to the cycle of the year:

"Here, indeed, the cycle of the year re-presents to us the mystery of our salvation, the mystery promised from the beginning of time, granted to the end of time, continuing without end" (XXII, 1).

In this passage Leo combines the traditional Antique view of time as cyclical with the linear Christian notion. Time begins and ends, but within this span there is a recurring, cyclical renewal of the mystery that can be compared to the annual renewal of Nature. It should be noted that while the Eastern writers concentrate on the origin of the Incarnation, the conception of Christ, Leo stresses the end of the process, His birth. The vehicle of this process is in both cases the Virgin Mary, and it is therefore natural that images referring to the renewal and regeneration of the creation, which the Incarnation had brought about, should be included in a church dedicated to her (such as S. Maria Maggiore). The Nile, which was the archetypical image of renewal and regeneration in Antiquity, was chosen for the purpose.

A fringe benefit, one might say, of associating the Nile with Mary was that the river was wrested from Isis, with whom it was traditionally connected. The feasts of Isis were celebrated as late as the fourth century (and in private contexts probably even later), and the Church was interested in uprooting her cult and indeed her memory. ${ }^{24}$ Compositional considerations may also have played a role in the choice of the Nile, for a stretch of water filled with small figures which could be varied

24. For Egyptian cults in Late Antiquity see Alföldi 1937; Alföldi 1965-1966; Takács 1995, 119-129; Ensoli 2000; Ensoli 2003. 
ad infinitum and extended as far as one wanted was the ideal termination of an apse decoration. Like many authors I believe that the motif of the vigorous peopled scrolls framing Christ and His mother in Torriti's apse was also borrowed from the late-antique decorative scheme, as it embodies the concept of a renewal of Nature.

\section{The fifth-century mosaics in the nave and on the triumphal arch}

We now finally come to the fifth-century mosaics still in situ in the basilica. Those in the nave are placed below the windows and were set in architectural frames in the shape of aediculae. Much has been written about these mosaics and their relation to illustrations in manuscripts. I would like to introduce another possible source of inspiration: woven or painted wall hangings with biblical motifs, of which the best preserved one is now in the collection of the Abegg-Stiftung at Riggisberg in Switzerland. Like the nave mosaics in S. Maria Maggiore, it shows scenes from the Old Testament, divided by architectural elements (in this case painted). ${ }^{25}$

The Riggisberg textile is of particular interest because it is much older than the mosaics in S. Maria Maggiore. A radio carbon dating gives the period AD 129-346, but for historical reasons it should be placed towards the end of this period, i.e. the first half of the fourth century. This shows that already a hundred years before the mosaics of S. Maria Maggiore were created, a well-developed iconography for Old Testament cycles existed. Some of the scenes are the same as in the later mosaics, but they are treated differently. This implies that there was a choice of models.

In his book on the mosaics of S. Maria Maggiore, B. Brenk mentions the possibility of a model in the shape of a papyrus roll. ${ }^{26}$ In the wall hanging in the Abegg-Stiftung we have such a roll, but made of textile, not of papyrus. It is quite feasible that the ultimate models for cycles such as these were papyrus rolls, but I think that painted or woven wall decorations may have served as intermediates between the putative rolls and the later mosaics.

It is well known that churches were decorated with textiles. Written sources often refer to costly fabrics dedicated to churches. In the context of the early Christian basilicas in Rome, it is interesting to recall two cryptic passages in the Liber Pontificalis regarding the Constantinian S. Salvatore, later S. Giovanni in Laterano, and the Constantinian S. Peter's. The texts speak of "cameram basilicae ex auro trimita in longum et in latum, lib. D.", and "cameram basilicae ex trim(it)a auri fulgentum." The apses of the basilicas were evidently covered with something golden, which is often assumed to have been plaques of gold leaf. However, it has been pointed out that the word trimita refers to textiles, in other words, the apses seem to have been covered in gold brocade. ${ }^{27}$ This could be

25. Kötsche 1993; Kötsche 2004; Schrenk 2004, 65-70.

26. Brenk 1975, 129.
27. Guarducci 1981, 803-806; Andaloro and Romano 2000, 96; Andaloro and Romano 2002, 74. 
quite heavy. That would explain the weight of the trimita in S. Salvatore, which is given as 500 Roman pounds (163.3725 kilos). One could well imagine sumptuous wall hangings - woven, not painted - as the source of inspiration for at least some of the nave panels in S. Maria Maggiore. In the panel showing Moses with Pharaoh's daughter, the gold brocade dresses of the court ladies could have been made of real gold brocade, a material stunt which the colour-loving artists of Late Antiquity would have appreciated.

It should also be noted that many of the figures and objects included in the painted textile in the Abegg-Siftung are named in their accompanying inscriptions. Without these names it would have been difficult to interpret some of the scenes. The Abegg textile is not over-large for a wall decoration, being $146 \mathrm{~cm}$ high and between 430 and $436 \mathrm{~cm}$ long. Assuming it was not placed so high, the letters could easily have been read. It has been pointed out by Beat Brenk especially that many of the scenes in the nave of S. Maria Maggiore are difficult to interpret because they are so static, showing people in conversation. ${ }^{28}$ But if the model on which they were based had been a wall hanging with names added, the choice of subjects would be more understandable. The meaning of the scenes would still have been grasped only by the literate, but that part of the public could at least see who or what was represented without needing to have a deep knowledge of all the biblical texts. The names "Herodes", "Bethleem" and "Hierusalem" on the triumphal arch of S. Maria Maggiore may be relics of such a practice, but in the nave there would have been little point of inscribing the figures with names because of the comparatively modest size of the panels and because they would in any case have been illegible given their great distance from the spectators below.

Of the mosaic panels in the nave the first seven (seen from the apse) on the right side show episodes from the life of Moses in Egypt. I shall here only concern myself with the first of them, which is in reality the second, the first one having disappeared. In the upper section is represented Moses being returned by his nurse to Pharaoh's daughter, in the lower section Moses and the pagan philosophers at Pharaoh's court (Fig. 6). ${ }^{29}$ The latter scene is unusual since it has no biblical source. It is known to us through the Vita Mosis by Philo of Alexandria, but versions by other authors may of course have been available in Late Antiquity.

Pharaoh's daughter, dressed as a late-antique princess, is shown enthroned on the left, extending both hands towards a jewellery casket which is presented to her by one of the two maids standing by her side. Moses is being gently pushed towards her by his nurse (who is in reality his mother). The scene shows him being accepted by Pharaoh's daughter, and can be regarded as his adoption. Moses is represented as a young nobleman wearing the typical lateantique Dienstkostum: a long chlamys over an embroidered tunic. The chlamys is purplish blue in colour with a golden tablium.

28. Brenk 1975, 126-128.
29. For this mosaic panel see especially Brenk 1975, 77-80. 


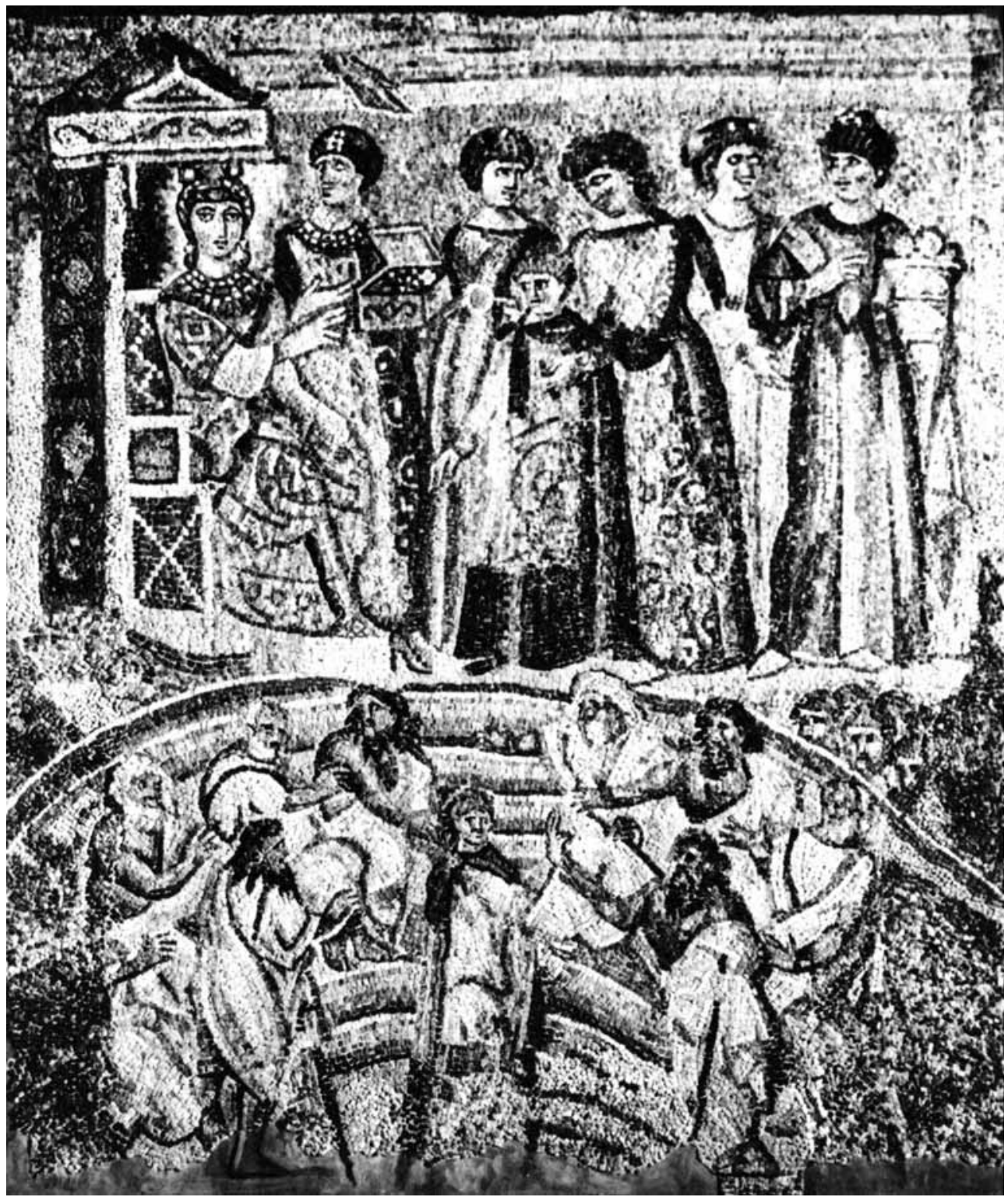

Fig. 6 - S. Maria Maggiore, mosaic in the nave showing Moses at Pharaoh's court. Photo: (Musei Vaticani neg. XXXVI.32.38/1).

The motif of a noblewoman being offered a jewellery casket is an ancient one - it suffices to recall Greek funerary monuments. The casket is open, and Pharaoh's daughter evidently intends to take something out of it. Since she is already profusely adorned with jewels, Moses is the likely recipient of the object. I believe that Pharaoh's daughter is going to give him a fibula, which he is lacking. This ornamental brooch formed an important part of the late-antique 
Dienstkostum, and Moses is seen wearing it in the lower section of the mosaic. Despite its small scale one can discern a fibula of the cross-bow type, of Germanic origin and commonly worn by military officers and high civil servants. In the present context the fibula is the outward sign that Moses is accepted as the adopted son of Pharaoh's daughter.

The lower section of the mosaic shows Moses in the midst of a group of gesticulating philosophers. A lively discussion is clearly going on, dominated by Moses, whose superior calmness contrasts with the agitation of the philosophers. According to Philo, the philosophers were not only Egyptian. ${ }^{30}$ Some had come from far away, either of their own accord or because they had been invited to Pharaoh's court. Moses, however, soon surpassed them all in wisdom. In a Christian context Moses is seen as a prefiguration of Christ, and as he came to surpass the philosophers in learning, so the divine wisdom of Christianity was to eclipse the traditional pagan wisdom. Several Christian authors regard Pharaoh's daughter as a prefiguration of the Ecclesia ex gentibus turning to Christ. ${ }^{31}$

Though the symbolism of each of these two scenes is confirmed by various Early Christian authors, their juxtaposition, which constitutes a hapax, asks for a more specific explanation. In his book on the Life of Moses, Gregory of Nyssa explicitly draws a parallel between Pharaoh's daughter and pagan philosophy. ${ }^{32}$ He compares her to philosophy because both, according to him, are barren. Just as she is no real mother, but a surrogate mother, so pagan philosophy is a surrogate for the true wisdom of divine origin. Since Gregory of Nyssa was a famous and influential author, known both in the East and the West, it is not too far-fetched to suppose that the erudite person responsible for devising the Old Testament cycle in S. Maria Maggiore knew his book on Moses and used it. Gregory also includes the story of Moses and the pagan philosophers, which he probably borrowed from Philo, whose Vita Mosis seems to have influenced him..$^{33}$ In Gregory's interpretation Pharaoh's daughter is seen in a less positive light. Like the scene below her, she represents the futility of pagan wisdom, which must be abandoned, just as Moses abandoned Pharaoh's court. Since the second mosaic panel in the series represents a surrogate mother, one may suppose that Moses' real mother was shown in the first, perhaps in the act of leaving him in his basket among the reeds growing by the banks of the Nile (another Nilotic motif). It should be noted that several of the mosaic panels in the nave are concerned with marriage and motherhood, a choice which may have been influenced by the fact that S. Maria Maggiore was dedicated to a mother.

30. Philo of Alexandria, Vita Mosis, 21-25.

31. Brenk 1975, 119-120 with n. 116
32. Gregor of Nyssa, Vita Mosis, 10-11.

33. Meredith 1995, 72-75. 
Beat Brenk has already drawn attention to the relationship between the second panel on the right of the nave (with Moses and Pharaoh's daughter) and the second panel from above on the right of triumphal arch (Fig. 7). ${ }^{34}$ Similar compositional principles recur in the two scenes, which show a certain parallelism in their content (Moses admitted to Pharaoh's court, Jesus being received by an Egyptian ruler). Though the ruler in the scene on the triumphal arch is not named, he is generally identified with Aphrodisius, the ruler of the otherwise unknown Egyptian city of Sotinen mentioned in the apocryphal Gospel of Pseudo-Matthews (XXII-XXIV).

According to the text, the child Jesus and his parents first entered the city and then the local temple, which is described as the Capitolium of Egypt. In reality it seems to have been a local Pantheon, containing 365 statues, one for each day of the year. No sooner had the Virgin and her Son set foot in the temple than all the statues fell to the ground and were shattered into pieces. The priest of the temple summoned the governor Aphrodisius, who, instead of punishing the culprits, fell down and adored the divine Child. Afterwards he explained to his army and his friends that he did this because he found it prudent, as he did not wish to meet the end of Pharaoh, who had not heeded the portents connected with Moses and the exodus of the people of Israel. Here we have a clear reference to the first part of the mosaic cycle on the adjacent side of the nave, which helps explain the choice of the Aphrodisius episode in this section of the triumphal arch.

More than once it has been pointed out that the scene on the triumphal arch does not correspond with the text, as there is no reference to the fallen statues. ${ }^{35}$ This, however, is quite natural, since the episode with the statues occurred inside the city, whereas the scene in S. Maria Maggiore takes place outside it. The city walls are seen in the background, with a large open gate through which the ruler, whom we may call Aphrodisius, has just passed with his escort. Behind his bodyguard we see what must be stunted, misshapen fasces with axes stuck into them, another indication that we are outside the city walls. Aphrodisius and his retinue and the Holy Family form two distinct groups. When somebody (especially the ruler) left the city at the advent of a visitor, it was a sign that the latter was at least on equal footing with the inhabitants of the city, and generally superior to them. Here again Beat Brenk has made an interesting observation: Aphrodisius and the man beside him are looking towards the Holy Family, who in turn look straight ahead; they are

34. Brenk 1975, 78. For the scene see Wilpert 1916, 489-491; Cecchelli 1956, 235; Wellen 1961, 113 115; Brodsky 1966, 87-91; Grabar 1968, 49, fig. 139; Brenk 1975, 27-30; Wilpert and Schumacher 1976, 317. Spain 1979, 519-525; Sieger
1987, 86-88; Gandolfo 1988, 112-114; Sperduti 1996, 66-67; Bisconti 2000, 19.

35. Cecchelli 1956, 235; Brenk 1975, 29; Wilpert and Schumacher 1976, 317; Spain 1979, 520521; Gandolfo 1988, 113. 
not greeting, but being greeted, or rather, honoured. ${ }^{36}$ Like Moses in the panel with Pharaoh's daughter, Aphrodisius is wearing a purplish-blue chlamys with a golden tablium. His dress has been termed "imperial", but it is not completely so. In fact Aphrodisius wears the almost-but-not-quite imperial dress of late-antique client kings, befitting his status as a dux, as he is termed in the Gospel of Pseudo-Matthew. The purple chlamys with a golden tablium corresponds to the attire that Justinian, according to Procopius, gave to Armenian satraps. ${ }^{37}$ They were also given red boots "of the sort which only the Roman emperor and the Persian king are permitted to wear" and fibulae with three pendants, another imperial prerogative. ${ }^{38}$ Aphrodisius' footwear is red, but his fibula has only two pendants. Such niceties were probably obvious only to the cognoscenti, but Aphrodisius lacks the most characteristic attribute of a Late Roman emperor, the jewel-studded diadem. Instead he wears the plain fillet of Hellenistic rulers, which in Roman art distinguished kings, not emperors. Aphrodisius therefore falls into the category "minor royalty" from a late-antique point of view. ${ }^{39}$

He is accompanied by a person who seems out of place in an adventus scene: a man with unkempt hair and beard wearing only a pallium. He is a philosopher, and more precisely of the Cynic school. Similar figures are found in the scene showing Moses and the pagan philosophers, another element linking the two scenes. In late-antique art the Cynic philosopher came to represent the pagan philosopher as such. This is probably due to the fact that the apostles were shown as philosophers wearing tunic and pallium. It could therefore be difficult to distinguish the average well-dressed apostle from the average well-dressed pagan philosopher, but the Cynics stood out and would not easily be confused. The philosopher in the mosaic, who in this context is likely to represent paganism, greets the child Christ in the same way as Aphrodisius. He is consequently shown as being friendly. This is perhaps why the author of the mosaic has placed this scene outside the city, before Christ entered the temple, because a pagan would hardly be cordial to someone who had just destroyed 365 idols.

Several authors have remarked on the inner relationship between the sections of the mosaic on the triumphal arch of S. Maria Maggiore, where the Incarnate Christ appears to various representatives of His people (Jews and pagans). Basing herself on the sermons of Leo the Great, J. D. Sieger especially has underscored the connection between the Flight into Egypt and the Herod scene below, because Herod's order to massacre all male infants in Bethlehem and its environs was the direct cause of Christ's journey into Egypt, the traditional land of idolatry to many Early Christian authors, but also the traditional land of wisdom in Antiquity. ${ }^{40}$ True, this wisdom was pagan, and consequently surrogate wisdom, but in the Aphrodisius panel its representatives are shown to

36. Brenk 1975, 28.

37. Procopius, de aedeficiis, 3, 19-23.

38. Procopius, de aedificiis, 3, 3, 23.
39. For the imperial fibula and diadem in Late Antiquity see Stout 2001, 82-91.

40. Sieger 1987 , especially $86-88$. 


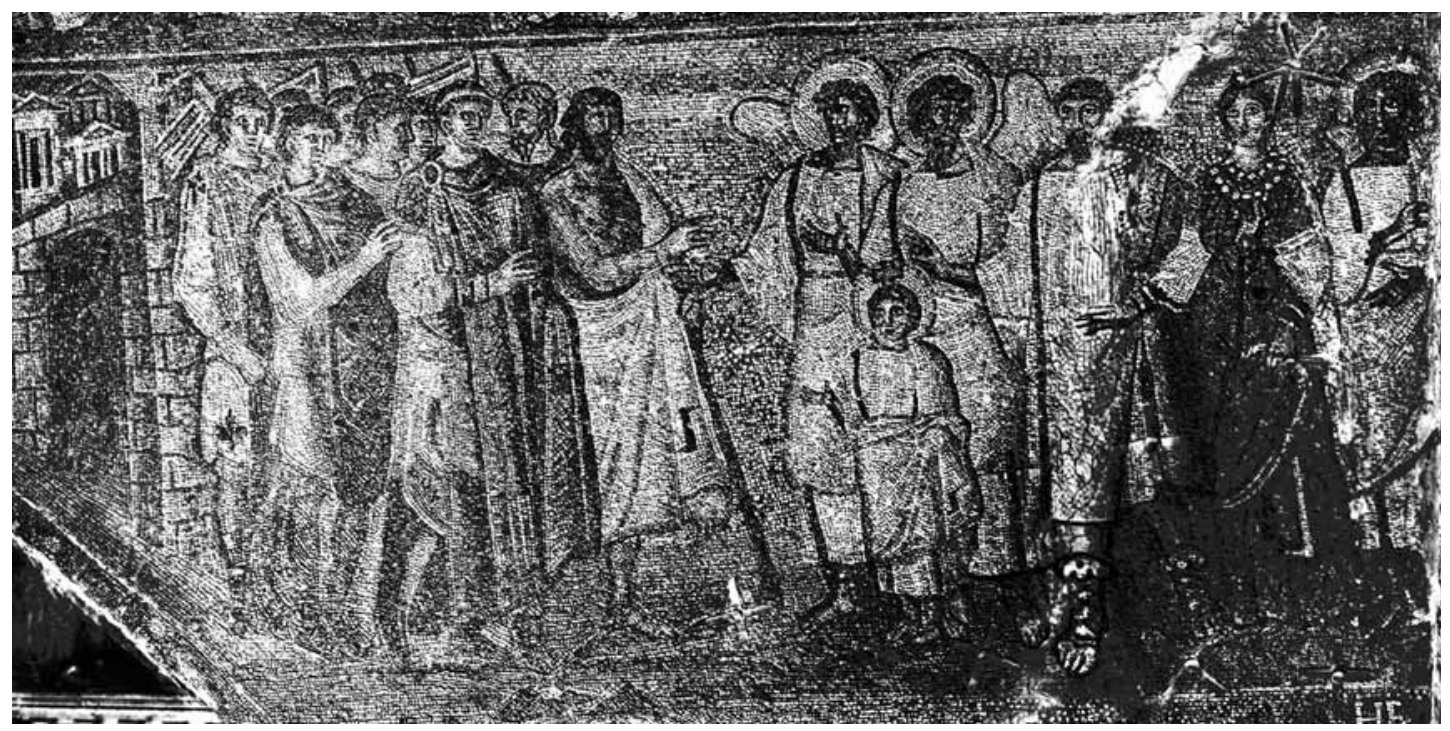

FIG. 7 - S. Maria Maggiore, triumphal arch. Jesus received by an Egyptian ruler. (Photo: Musei Vaticani neg. XXX.32.1)

acknowledge its inferiority and pay homage to Christ. Herod, on the other hand, is completely blind to reason.

The figures of Herod are not well preserved, notably the one on the left, but enough remains to establish that he wore military garb. His chlamys and diadem are similar to those of Aphrodisius, indicating him as a client king. Perhaps to avoid confusion between the two rulers, Herod has his name inscribed above him in the scene with the Magi. To our way of thinking, it would be more logical to name the obscure Egyptian ruler, as Herod ought to have been recognizable to those who knew their Gospel. However, it seems to have been more important to the designer of the mosaic to label him and thus show who the real villain is.

Leaving the realm of Egypt, I shall now say a few words about the other sections of the mosaic. A link with Egypt is still present in the section above the Flight into Egypt, where an angel exhorts Joseph to bring his family there. The rest of the panel is taken up by a scene which, notwithstanding some anomalies, may be identified with the Presentation in the Temple (Fig. 8). ${ }^{41}$ One of the most peculiar features of this scene is the importance given to the three figures in the middle, a man and a matronly woman with an angel between them. The hands of the woman and the angel perform gestures which in Roman art denote

41. Wilpert 1916, 480-483; Grabar 1936, 213-217; Cecchelli 1956, 219-220; Wellen 1961, 101-109; Thérel 1962, 158-162; Brodsky 1966, 58-66; Matthiae 1967, 93; Brenk 1975, 19-24, 41-42; Wilpert and Schumacher 1976, 316. Spain 1979,
535-536; Stritzky 1980; Matthiae and Andaloro 1987, 44; Gandolfo 1988, 112; Ahlquist 1991, 112-120, 127-129, 131-132; Marini Clarelli 1996, 332-334; Sperduti 1996, 66; Bisconti 2000, 19; Warland 2003, 127-134, 138-139. 
speech, whereas the man is gesticulating either towards the woman, or, more probably, towards an elderly man who comes rushing from the right with his cloak covering his outstretched hands.

The Romanitas of this scene has been noted by several authors, who have remarked that the temple in the background, which in this context must be the Temple of Jerusalem, looks like that of Venus and Roma in Rome, called the Templum Urbis. ${ }^{42}$ Recently Rainer Warland has suggested that the row of masks running along its frieze may be the enormous gorgoneia that decorated the Templum Urbis ${ }^{43}$ Despite the criticism voiced by G. Steigerwald, ${ }^{44}$ I find Warland's hypothesis attractive. More controversial is his identification of the man rushing forward to receive Christ with Peter, though the resemblance between this man and Peter has been noticed before..$^{45}$ Traditionally he is identified with the old Simon, and the man talking to the prophetess Anna, with Joseph. ${ }^{46}$

I shall not go into these interpretations here, but merely remark that whoever Anna's interlocutor may be, he is completely dwarfed by the prophetess, whose bulk and importance are highly unusual in Presentation scenes. Such scenes were especially popular in Byzantine art, where Anna is seen standing modestly in the background, the limelight being given to Simon with the Divine Infant in his arms. ${ }^{47}$ In the mosaics of S. Maria Maggiore she dominates the scene, for reasons that I shall return to later. The left part of the upper mosaic section is mostly taken up by the Annunciation, which is of course the event that sets all the others in motion. Far less space is devoted to the second scene, showing an angel appearing to Joseph.

Directly below the Annunciation its result, namely the Incarnated Christ, is seen enthroned. The scene may be described as a highly unusual version of the

42. Grabar 1936, 216-217; Wellen 1961, 103-104; Brodsky 1966, 67; Wilpert and Schumacher 1976, 316; Warland 2002 127-133; Warland 2003, 130-132; Steigerwald 2003.

43. Warland 2002, 28-29; Warland 2003, 130-132.

44. Steigerwald 2003, 79-80.

45. Warland 2002, 30; Warland 2003, 133-134 (already suggested by Thérel 1962, 161-162, n. 5; and Brodsky 1966, 66-69). For remarks on the resemblance between Simon and Peter Grabar 1936, 225, n. 2; Wellen 1961, 102; Brenk 1975, 23-24; Stritzky 1980, 137-139. For criticism of Warland's hypothesis see Steigerwald 2003, 81-82.

46. Ahlquist 1991, 138-139, gives a list of interpretations of the main figures of this panel up to 1990. It is unfortunate that this useful article is written in Swedish, which makes it accessible only to the few. For later authors see my n. 41 and the bibliography in Warland 2003, 140-
141. See also Steigerwald 2003, 74-77. Due to a superficial resemblance to a dextrarum iunctio scene (this observation goes back to Wilpert 1916, 481, who remarked, however, that the resemblance was fortuitous), some authors (Brodsky, Spain, Ahlquist) have suggested that a marriage (symbolic or real) is actually being contracted. This is not the case, because the hands are not joined, the couple do not look at one another and the woman is dressed in sombre clothes unsuitable to a bride. Compare the real marriage scenes in the mosaics of the nave in S. Maria Maggiore, which show the marriages of Jacob and Rachel and Moses and Sephora respectively: Cecchelli 1956, pls. XX and XXX; Karpp 1966, pls. 61 and 90; Wilpert and Schumacher 1976, pls. 32 b, 38; Nestori and Bisconti 2000, pls. XV and XXII.

47. See Maguire 1980-1981, figs. 5-9, 13; Maguire 1981, 84-90, figs. 90-91. 


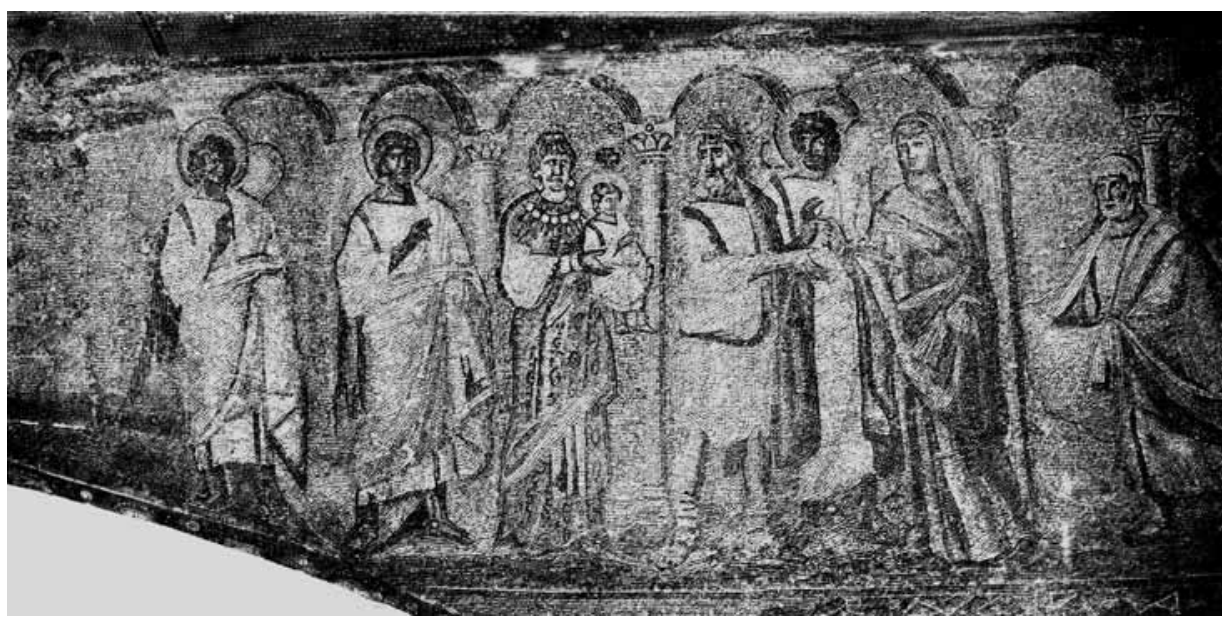

FIg. 8 - S. Maria Maggiore, triumphal arch. The Presentation in the Temple (Photo: Musei Vaticani neg. XXXI.27.9).

Adoration of the Magi. Here Christ is flanked by two women (Fig. 9). ${ }^{48}$ Their respective seats indicate a certain difference in rank. Christ is sitting on a purple cushion on a sumptuously jewelled throne. In front of it there is a jewelled footstool, which His feet do not reach. The two women do not sit on thronoi, but on backless chairs; the one on the left has a cushion and a more elegant chair than the one of the right, who has a sturdier chair and no cushion. Both women have plain footstools on which one foot is resting while the other is suspended in the air. It is often said that the woman on the right supports her foot on a sort of hillock or hump, but since that would be out of place on a footstool, the blue shape under her foot must be a shadow.

Since the woman on the left is shown in the costume of a femina clarissima worn by Mary in other scenes in the S. Maria Maggiore mosaics, she is generally identified with her. The identity of the woman on the right, who wears a more elegant version of the dress of the prophetess Anna, has been much disputed. ${ }^{49}$ In his magisterial treatment of this scene, A. Grabar has shown that it must have a model taken from the realm of imperial iconography. He and several scholars after him have referred to a consular diptych in Halberstadt Cathedral, showing two enthroned emperors flanked by the personifications of Rome and Constan-

48. Wilpert 1916, 485-487; Grabar 1936, 227-228; Cecchelli 1956, 203-219; Wellen 1961, 110-113; Thérel 1962; Brodsky 1966, 49-58; Matthiae 1967, 93-94, Grabar 1968, 47, fig. 134; Brenk 1975, 24-27, 39-40, 42-43; Wilpert and Schumacher 1976, 317; Spain 1979, 526-530; Matthiae and Andaloro 1987, 44; Ahlquist 1991,
112-120; 127, 129-131; Gandolfo 1988, 112-114; Marini Clarelli 1996, 335-337; Sperduti 1996, 66; Bisconti 2000, 19; Warland 2003, 134-139; Calcagnini 2002, 1934-1935.

49. Ahlquist 1991, 129-131, has given a list of the various identifications up to 1990 of the two women flanking the throne of Christ. 


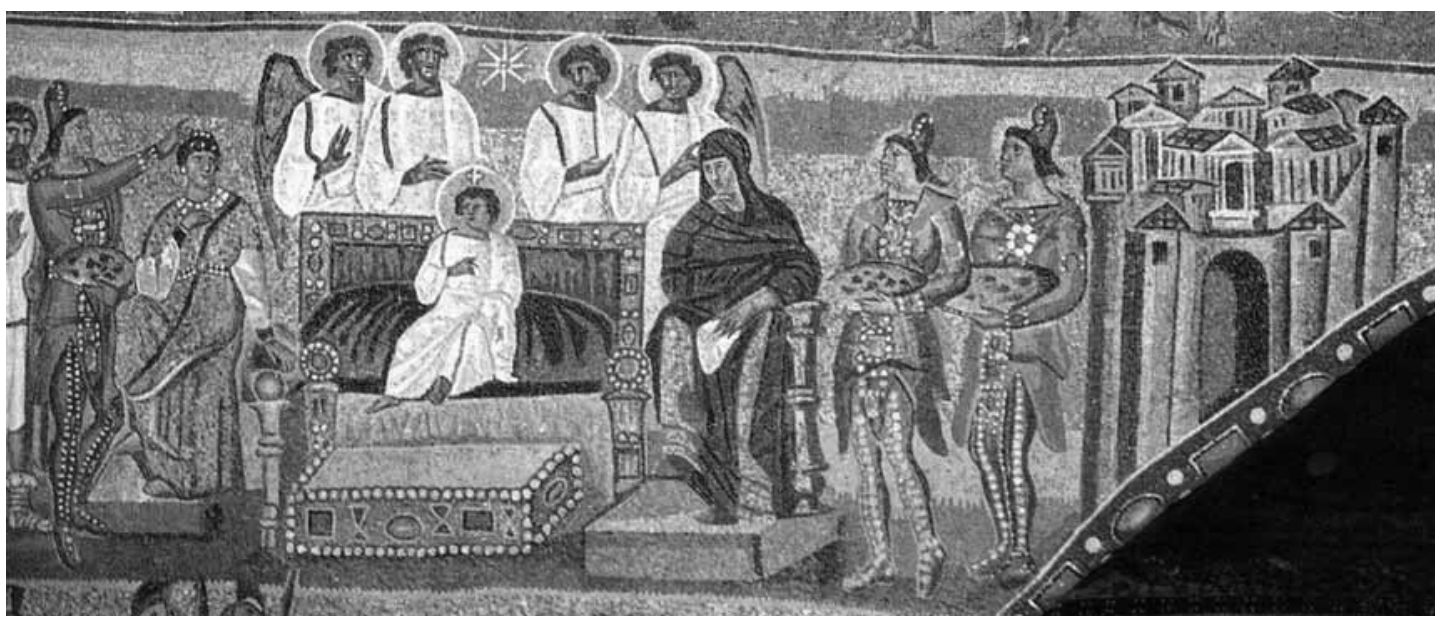

Fig. 9 - S. Maria Maggiore, triumphal arch. The Adoration of the Magi, detail. (From Karpp 1956, pl. 6)

tinople. ${ }^{50}$ Between them stands a woman, presumably Concordia. The model for the S. Maria Maggiore mosaic was hardly a diptych, but a painting. In fact, a sermon by Petrus Chrysologus indicates that such paintings were widespread. ${ }^{51}$ In the mosaic Concordia has naturally been dispensed with, and instead four angels stand behind the throne. The two on the right turn their heads backwards to look at Christ, while the two on the left gaze at a star above His head. The city personifications have been replaced by the two women.

Grabar's hypothesis may explain why the model for Mary is a city personification, not, however, Rome or Constantinople, but the Tyche of Antioch, immortalized by a much-copied statue by the Hellenistic sculptor Eutychides. ${ }^{52}$ The type was well known in Late Antiquity, as testified by a silver statuette from the Esquiline treasure in the British Museum, which was probably hidden during Alaric's sack of Rome in 410 (Fig. 10). ${ }^{53}$ The fact that Mary is shown according to the Tyche of Antioch scheme is puzzling; it is not to be explained by the fame of the model. Why not use the personifications of Rome or Constantinople, which were far more common in Late Antiquity? They are shown frontally, as would befit an enthroned person, whereas Mary's twisted pose, typical of Hellenistic art, is unusual in such a context. It is not necessary to show her like this to make her look towards her Son, because a turn of the head would have sufficed.

50. Grabar 1936, 227-228, pl. III; Thérel 1962, 156158, fig. 4; Grabar 1968, 79, fig. 202; Brenk 1975, 26, fig. 12; Warland 2003, 135-137, fig. 5.

51. Quoted in Kollwitz 1941, 34, n. 5.

52. Bieber 1961, 40, 49, 84, fig. 102; Moreno 1994,
158-164, figs. 206-209; Ridgway 2001, 233-237, figs. 115-116.

53. Weitzmann (ed.) 1979, 176-177 (text: Shelton, K. J.); Shelton 1981, 88, pls. 35, 42-43; Stutzinger 1983; Painter 2000, 491-493, no. 114 b. 


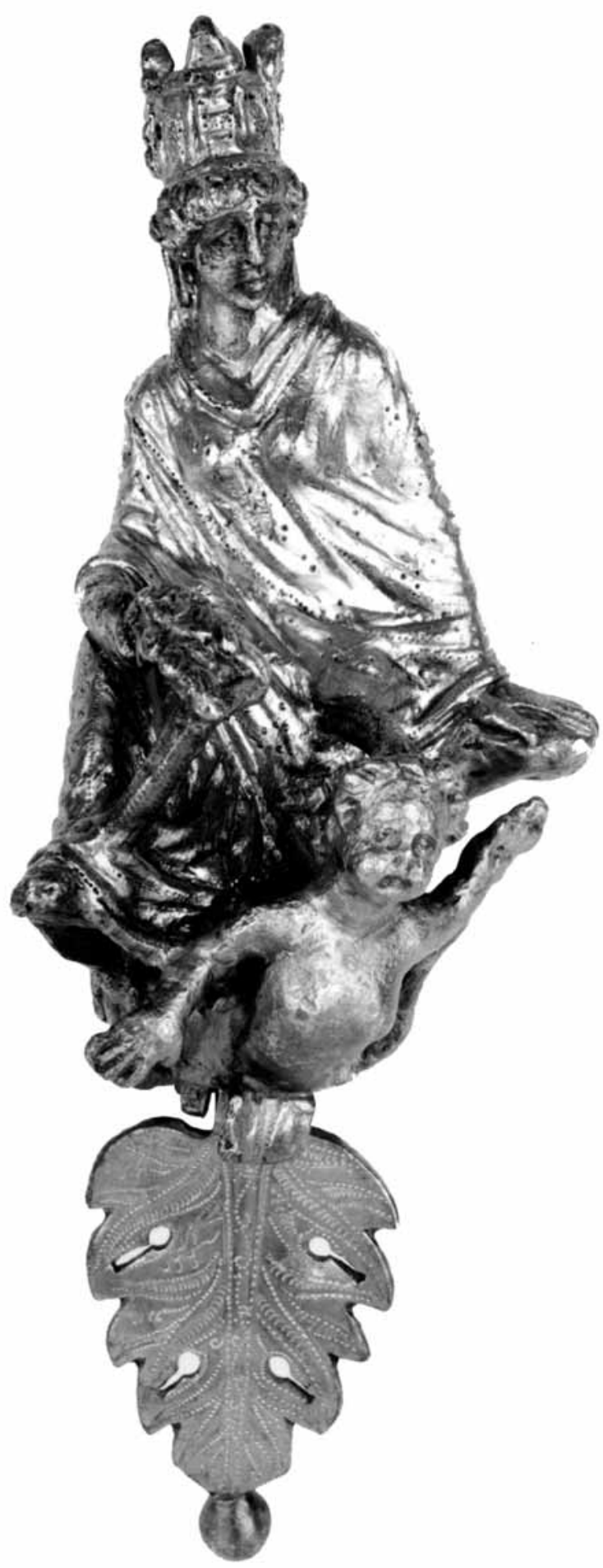

FIG. 10 - Personification of Antioch, silver statuette from Rome (Photo by courtesy of the trustees of the British Museum). 
I think the solution is to be sought in the woman on the right. At first glance the two look very different because of their dress, but apart from Mary's turn of the head, they are depicted according to the same scheme. Both have one foot in the air (probably the left one, as they may be assumed to sit cross-legged). Their right elbow is supported on their knee with the lower arm crossing the chest, while the left arm is supported with hand or elbow on the chair. They are clearly meant to be compositional pendants. Since the position of Mary deviates from the usual scheme, one may guess that she has adapted herself to her partner. Who can this woman be? Many identifications have been adduced: Eve, Anna the prophetess (Lk 2:36), Anna the mother of Mary, Christ's midwife, Salome, Rachel, Sapientia Dei, Ecclesia ex gentibus and Ecclesia ex circumcisione (or simply Ecclesia), or a Sibyl. But biblical women (Eve etc.) are practically never shown outside narrative contexts with the exception of Mary, who is already present on the left. Therefore it is more probable that the enigmatic woman is some kind of emblematic figure such as Sapientia, Ecclesia or the Sibyl. Her dress, which is that of the Roman matron, is suitable to all three, but perhaps her posture may reveal something more. To sit with a hand under chin is generally the pose of thinking persons, for instance philosophers, in ancient art. Ecclesia is perhaps the least likely of the three to be represented as a philosopher. One would expect a more active figure such as the Ecclesiae in S. Sabina and S. Pudenziana, which are represented speaking or crowning the apostles. The pensive attitude would be more suitable to Sapientia and the Sibyl. The latter was of course a pagan figure, but as the written sources collected by authors in favour of this interpretation testify, she was fully acceptable in an early Christian context, being regarded as one of the prophets who had announced the birth of Christ. ${ }^{54}$

When I opt for the Sibyl, it is because of her position as a prophetess and consequently her relationship to Anna in the Presentation panel. Anna's similarity to the seated woman has often enough been remarked upon, to the extent of identifying the two. I believe that the prominence given to Anna stems from the fact that both she and the Sibyl are female prophets. The two monumental women emphasize one another. The closest the Romans came to a prophet was a Sibyl, and a female Jewish prophet like Anna must have been a perfect reminder that female prophets were not peculiar to the Romans. The accent on Romanitas, represented by the Templum Urbis in the Presentation scene, would have reminded the spectators that both Anna and the Sibyl announced the Incarnation in the Roman realm. For the Church of Rome it was important to point out that the spread of Christianity presupposed the Roman Empire, which made it possible to divulge the Gospel if not to all, at least to a large part of the population of the inhabited world.

54. Thérel 1962, 158-166; Marini Clarelli 1996, 335-337;

Warland 2003, 137-138; Geyer 2005/2206, 316-317. 
There were good theological and ideological reasons for including the Sibyl in the mosaics in S. Maria Maggiore, but one problem remained for the designer: how to get this message across to the public, seeing that the Sibyl was not named? The answer is: by using the tried and trusted figure of the Sibyl, which shows her as she is represented in the mosaic: seated with one foot suspended in the air, supporting herself one arm with the hand of the other under the chin, and accompanied by one or more books. In this way she is represented on Roman coins, for instance. ${ }^{55}$ One is reminded by a passage from Hermas' book Pastor, a second-century work, where Hermas in a dream sees an enthroned woman with a book in her hands. An angel asks him: "Who do you think this is"? He answers: "The Sibyl". The angel informs him that he is wrong: it is the Church..$^{56}$ This shows two things: the Sibyl could be assimilated to the Ecclesia, and, more important in my context: when you showed somebody the image of an enthroned woman with a volumen, he immediately guessed that a Sibyl was intended. While the Sibyl in the late-antique Vergilius Vaticanus Cod. 3225 is shown in action, and consequently standing or walking, ${ }^{57}$ a seated woman in a pensive pose was evidently the right thing when you wanted to show an image of the Sibyl per se.

With regard to the interpretation of the seated woman as the Sibyl, H. Brandenburg has remarked that "Die nachdenkliche Matrone [...] ist eine sehr allgemeine Formel [...]" ${ }^{58} \mathrm{He}$ is seemingly right in that. Women seated crosslegged with a hand to their chin or supporting their head in their hand are by no means uncommon. In ancient art, it seems that females shown in a pensive attitude are mostly thinking of something unpleasant, as they are often associated with sorrow and mourning. In this context it is enough to allude to representations of Electra, Penelope and various Provinciae Captae on Roman coins and monuments. ${ }^{59}$ Therefore the figure in the mosaic must be seen in its specific context.

In a scene showing the Adoration of the Magi, sorrow and grief are out of place. An erudite Roman of Late Antiquity would hardly see a Penelope in the matronly woman in the mosaic. It is clear that this woman is something more than the average pensive person, since she holds a volumen. In an Early Christian context (and not only there) this attribute is associated with a text, and very few female figures are associated with texts. The Sibyl and the Ecclesia were among those figures. Since the Sibyl, in addition to holding a volumen, was traditionally

55. For representations of the Sibyl see LIMC VIII,1, 755-756 (text: Caccano Caltabiano, M.); LIMC VIII,2, 548.

56. Hermas, The Pastor, 2,2, 8,1. See also the edition by R. Joly (Sources Chrétiennes 53 bis, Paris 1986, 96 with n. 1.

57. de Wit 1959, pls. 18-22; LIMC VIII,2, 549.

58. Brandenburg 2003, 514.

59. LIMC III,1, 709-719 (text McPhee, I.), LIMC
III,2, 543, I,2,7,8, 544, I,9,10,12,17, 546, I,24,28, 548, I,56 (Electra); LIMC VII,1, 291-295 (text: Hausmann, Chr.), LIMC VII,2, 225, 2a-1, 2a-2, 226, 3-8c, 227, 10, 16, 18a, 18d, 228, 18c, 18e, 229, 33a, 230, 33b,c,e (Penelope). For examples of Provinciae Captae see for instance Toynbee 1967, pl. IX, 13, 25, pl. XI, 26, 27, pl. XII, 13-23, pl. XIII, 28, 29, pl. XIV, 24, 25, pl. XVI, 19-21, pl. XVII, 1-3, pl. XXV, 1, pl. XXVI, 3. 
shown seated with a hand under chin, I believe that the designer of the mosaic used this familiar image to facilitate the interpretation of the figure. Persons well versed in Christian literature may of course have associated her with the Ecclesia as well, as the quotation from Pastor indicates.

The mosaics on the triumphal arch of S. Maria Maggiore show the Incarnated Christ in the guise of a Child appearing to various gentes, both Jews and Gentiles. The gentes are indicated by chosen representatives, who all embody wisdom. In my opinion the concept of wisdom is crucial in the interpretation of these mosaics. One finds the Greek wisdom represented by the philosopher accompanying Aphrodisius, the Oriental wisdom represented by the Magi, the Jewish wisdom represented by the prophets Anna and Simon, and the Roman wisdom represented by the Sibyl. All these wise men and women pay homage to Christ. Herod constitutes a negative foil. He is lerodes, silly, as the Akathistos hymn calls him. ${ }^{60}$ The images of Wisdom paying homage to Christ exhort the spectators to do likewise, and therefore it is likely that He was the focus of the original apse mosaic, either alone or shown seated on his mother's knees.

The mosaics of S. Maria Maggiore are in many ways unique. Certain motifs recur in later contexts, but the ensemble was not imitated. The reason for this may have been in part theological. As Marini-Clarelli has remarked, the insistence on the divinity of Christ from the very beginning of his existence was probably not the result of the Ephesian Council of 431, but rather of the theological battles preceding it. ${ }^{61}$ After the victory of the anti-Nestorians it was no longer necessary to focus so strongly on Christ's divine nature; on the contrary, a new heresy, Monophysitism, which denied His human nature, loomed on the horizon.

However, not only the theological programme, but the whole way of presenting it, is without successors. This is presumably because it did not appeal to larger sections of the public. In his famous letter to Bishop Serenus of Marseille, Gregory the Great maintained that the images decorating churches constituted a Bible for the illiterate, in other words for the poor. ${ }^{62}$ The mosaics of S. Maria Maggiore are not a poor man's, but a rich man's Bible, comprehensible only to the literate elite. Those who could understand the figurative language of these mosaics were the aristocracy who sent out and received consular diptychs and related objects; who could appreciate the difference in dress according to the social status of the various persons represented; and who were able to discern whether a man was an emperor or a client king simply by counting the number of pendants on his fibula. In short, they were the kind of people who are nowadays able to see at a glance whether a Louis Vuitton bag is a fake.

I have said earlier that I think the models for the mosaics in S. Maria Maggiore may have been wall hangings or similar decorations in the mansions of the aristocracy. These models functioned well in their original settings, but their

60. Hymnos Akathistos, 10.

62. Hartmann 1899, 269-272.

61. Marini Clarelli 1996, 324-327. 
effectiveness as vehicles for the diffusion of the Christian message must have sensibly diminished once they were deprived of their written names and transferred to a large-scale context for presentation to a wider public. When a comprehensive decoration of an important Roman basilica was next carried out (as in St. Peter's and S. Paolo fuori le Mura), important changes were made. The two-tiered mosaic panels with many small figures, as well as the many cryptic scenes showing people conversing, were largely abandoned. Instead we find scenes filling the whole panel, generally showing larger and fewer figures, and the motifs are more easily recognizable. Action, not conversation, is stressed.

In this respect, we can compare the mosaics of S. Maria Maggiore with Trajan's Column (AD 113). ${ }^{63}$ Both were epoch-making monuments in their age; both were directed at a particular segment of society; and both, it seems, were later seen to be less effective means of propaganda than was originally intended. Like the S. Maria Maggiore mosaics, Trajan's Column represents an illustrated book (its reliefs constitute a volumen, in fact). The figures are in rather low relief, and, for such a large monument, small-scaled. The scenes are full of military and ethnic minutiae comprehensible only to those who had taken part in Trajan's campaigns. Like the S. Maria Maggiore mosaics, the reliefs on Trajan's Column contain many representations of mere onlookers: people who do nothing but passively witness what is taking place, whether it be attending sacrifices or listening to the Emperor's speeches.

When a new relief column was erected in Rome, that of Marcus Aurelius, an effort was evidently made to improve the readability of the reliefs from bottom to top: the relief bands are higher and consequently fewer, the figures taller and in higher relief. ${ }^{64}$ Ethnic and military correctness, nuances of ethnographic character or military uniform, which would chiefly have been appreciated by segments of the army, have largely been given up in favour of standardized Roman soldiers and standardized barbarians. The many scenes with standing onlookers have been replaced by action.

In the great cycles from St. Peter's and San Paolo fuori le Mura we see how the subtlety of S. Maria Maggiore has given way to greater readability. The biblical scenes in the former churches are closer to Gregory the Great's idea of the Bible for the illiterate; their figurative language is easier to explain and recognize. It has often been conjectured that Leo the Great, who was a deacon under Sixtus III, may have been responsible for the iconographic programme of the mosaics of S. Maria Maggiore because many of their themes recur in his sermons. But Leo's sermons are not original; they express the contemporary views of the Church of Rome. Leo the Great is generally thought to have been

63. Of the vast literature on this monument I shall here limit myself to citing two of the more recent publications: Settis (ed.) 1988 and Coarelli (ed.) 1999 (English version 2000).
64. Compare Andreae 1973, figs. 430 and 431. For the Column of Marcus Aurelius see Caprino et al. 1955; Becatti (ed.) 1957; Becatti 1960, 47-82. 
responsible for the cycles of St. Peter's and San Paolo fuori le Mura, ${ }^{65}$ and if he was responsible for the cycles of S. Maria Maggiore as well, he must have learned a great deal from his first experiment and corrected it. But it is also conceivable that somebody else, probably a person stemming from the Roman aristocracy or at any rate with good contacts with that stratum of society, outlined the iconographic programme of S. Maria Maggiore. Whoever was behind the cycles of St. Peter's and San Paolo fuori le Mura, his (or their) concepts were clearly the winners, since many of the scenes were copied in later times, contrary to those in S. Maria Maggiore. Clarity conquered elegance and subtlety. But the subtleties are responsible for the fascination of the mosaics of S. Maria Maggiore. They have made them the subject of endless debates, which will no doubt continue in the years to come.

Siri Sande

University of Oslo

IAKH

Blindernveien 11

N-315 Oslo

65. For this complicated question see Matthiae and Andaloro 1987, 55-59. 


\section{BIBLIOGRAPHY}

Adriani A. 1972: Lezioni sull'arte alessandrina, Naples.

Ahlquist A. 1991: "Ett bidrag til ecclesiaikonografin i senantikk tid: S. Maria Maggiore i Rom”, Teologisk tidskrift 1991:2, 109-132.

Ainalov D. V. 1961: The Hellenistic Origins of Byzantine Art, New Brunswick, New Jersey.

Alföldi A. 1937: A Festival of Isis in Rome under the Christian Emperors of the fourth century (Dissertationes Pannonicae, Ser. II, fasc. 7), Budapest.

Alföldi A. 1965-1966: "Die Alexandrinischen Götter und die Vota Publica am Jahresbeginn”, JbAC 8-9, 53-87.

Alföldi A. and Alföldi-Rosenbaum E. 1990: Die Kontorniat-Medaillons, Berlin-New York.

Alföldi-Rosenbaum E. 1971: "A Nilotic scene on Justinianic floor mosaics in Cyrenaican churches", La mosaïque greco-romaine II, Paris, 149-153.

Alföldi-Rosenbaum E. and Ward-Perkins J. 1980: Justinianic Mosaic Pavements in Cyrenaican Churches (Monografie di archeologia libica XIV).

Andaloro M. and Romano S. 2000: "L'immagine nell abside", in Andaloro M. and Romano S. (eds.), Arte e iconografia a Roma da Costantino a Cola di Rienzo, Milan, 93-132.

Andaloro M. and Romano S. 2002: "L'immagine nell'abside" in Andaloro M. and Romano S. (eds.), Arte e iconografia a Roma dal tardoantico alla fine del medioevo, Milan, 73-102.

Andreae B. 1973: Römische Kunst, Freiburg-BasleVienna.

Aurigemma S. 1958: Le terme di Diocleziano e il Museo Nazionale Romano (4th ed.), Rome.

Aurigemma S. 1960: Italia in Africa. Tripolitana I,1. I monumenti d'arte decorativa: I mosaici, Rome.

Becatti G. 1957: Colonna di Marco Aurelio, Milan.

Becatti G. 1960: La colonna coclide istoriata, Rome.

Bertelli C. 1997: "Richard Krautheimer e la Basilica Liberiana", in In memoriam Richard Krautheimer. Relazioni della giornata di studi. Roma 20 febbraio 1995, Rome, 41-60.

Bieber M. 1961: The Sculpture of the Hellenistic Age (Rev. ed.), New York.

Bisconti F. 2000 a: "Il programma decorativo di S. Maria Maggiore", in Nestori. A. e Bisconti F. (eds.) , Mosaici paleocristiani di Santa Maria Maggiore negli acquarelli della collezione Wilpert, Vatican City, 13-23.

Bisconti F. 2000 b: "Programmi figurativi", in Ensoli S. and La Rocca E. (eds.), Aurea Roma. Dalla città pagana alla città cristiana, Rome, 184-190.

Blake M. 1936: "Roman Mosaics of the second century in Italy", MAAR XIII, 67-214.

Brandenburg H. 2003: "Seduta del 5. aprile 2001", RivArchCr LXXIX, 513-519.
Brenk B. 1975: Die frühchristlichen Mosaiken in S. Maria Maggiore zu Rom, Wiesbaden.

Brodsky N. A. 1966: L'iconographie oubliée de l'Arc Éphesien de Sainte-Marie Majeure à Rome, Brussels.

Calcagnini D. 2002: "Le figure femminili nei mosaici paleocristiani degli edifici di culto romano", in Ecclesiae Urbis. Atti del congresso internazionale di studi sulle chiese di Roma, III, Vatican City, 1919-1938.

Caprino C. et al. 1955: La colonna di Marco Aurelio, Rome.

Cecchelli C. 1956: I mosaici della Basilica di S. Maria Maggiore, Rome.

Coarelli F. (ed.) 1999: La Colonna Traiana, Rome. (English ed. 2000.)

Cormack R. 2000: Byzantine Art, Oxford.

Danbolt G. 1978: "Die Taufbecken im Kloster S. Nilo in Grottaferrata”, ActaAAArtHist VIII, 143-173.

De Rossi G. B. 1876: "Oratorio privato del secolo quarto scoperto nel Monte della Giustizia presso le Terme Diocleziane", Bulletino di Archeologia Cristiano III, 37-58.

De Rossi G. B. 1899: Musaici cristiani e saggi dei pavimenti delle chiese di Roma anteriori al secolo $X V$, Rome.

de Witt J. 1959: Die Miniaturen des Vergilius Vaticanus, Amsterdam.

Ensoli S. 2000: "I santuari di Iside e Serapide a Roma e la resistenza pagana in età tardoantica”, in Ensoli S. and La Rocca E. (eds.), Aurea Roma. Dalla città pagana alla città cristiana, Rome, 267-287.

Ensoli S. 2003: "Roma, la "Babilonia d'Occidente" di Agostino e i culti isaici in età tardoantica", in Pasini P. (ed.), 387 d.c. Ambrogio e Agostino, le sorgenti dell'Europa, Milan.

Foucher L. 1965: "Les mosaïques nilotiques africaines", in La mosaïque gréco-romaine, Paris, 137-145.

Gandolfo F. 1987: "La Basilica Sistina: I mosaici della navata e dell'arco trionfale" in Pietrangeli, C. (ed.), Santa Maria Maggiore a Roma, Florence.

Geyer A. 2005/2206: "Bibelepik und frühchristliche Bildzyklen. Die Mosaiken von S. Maria Maggiore in Rom", RM 112, 293-321.

Grabar A. 1936: L'Empereur dans l'art byzantin, Paris.

Grabar A. 1968: Christian Iconography. A History of its Origins, New York.

Guarducci M. 1981: "Camerae fulgentes", in Letterature comparate. Problemi e metodo. Studi in onore di Ettore Paratore, II, Bologna, 799-817.

Guidi G. 1933: "La Villa del Nilo", Africa Italiana V, 1-56.

Hartmann L. (ed.) 1899: Gregorii I Papae Registrum Epistolarum II (Monumenta Germaniae Historiae), Berlin. 
Ibrahim L., Scranton R. and Brill R. 1976: Kenchreai, Eastern Port of Corinth. II. The Panels of Opus Sectile in Glass, Leiden.

Karpp H. 1966: Die frühchristlichen und mittelalterlichen Mosaiken in Santa Maria maggiore zu Rom, BadenBaden.

Kitzinger E. 1950: "Mosaic Pavements in the Greek East and the Question of a "Renaissance" under Justinian", Actes du VIe Congrès international d'études byzantines I, Paris, 209-223.

Kollwitz J. 1941: Oströmische Plastik der theodosianischen Zeit, Berlin.

La Regina A. (ed.) 1998: PalazzoMassimo alle Terme, Milan.

Maguire H. 1980-1981: "The Iconography of Symon with the Christ Child in Byzantine Art", D.O.P. 34-35, 261269.

Maguire H. 1981: Art and Eloquence in Byzantium, Princeton.

Maguire H. 1987: Earth and Ocean: the terrestrial world in Early Byzantine art, University Park.

Marini Clarelli M. V. 1996: "La controversia nestoriana e i mosaici dell'arco trionfale di S. Maria Maggiore", in Bisanzio e l'occidente: arte, archeologia, storia. Studi in onore di Fernanda de'Maffei, Rome, 323-344.

Matthiae G. 1967: Mosaici medioevali delle chiese di Roma, Rome.

Matthiae G. and Andaloro M. 1987: Guglielmo Matthiae, Pittura romana del medioevo, Secoli IV-X, Vol. I, aggiornamento scientifico e bibliografia di M. Andaloro, Rome.

Matthiae G. and Gandolfo F. 1988: Guglielmo Matthiae, Pittura romana del medioevo, Secoli XI-XIV, Vol. II, aggiornamento scientifico e bibliografia di F. Gandolfo, Rome.

Menna M. R. 1991:"I mosaici torritiani, Franz Wickhoff e le "Immagini" di Filostrato", Studi Romani XXXIX,3-4, 236-251.

Meredith A. 1995: The Cappadocians, London.

Meyboom P. G. 1995: The Nile Mosaic of Palestrina: early evidence of Egyptian religion in Italy, Leiden.

Moreno P. 1994: Scultura ellenistica, Rome.

Nestori A. and Bisconti F. 2000: I mosaici paleocristiani di Santa Maria Maggiore negli acquarelli della collezione Wilpert, Città del Vaticano.

Oakeshott W. 1967: The Mosaics of Rome from the third to the fourteenth centuries, London.

Ovadiah R. and A. 1987: Hellenistic, Roman and early Byzantine mosaic Pavements in Israel, Rome.

Painter K. S. 2000: "Il tesoro dell'Esquilino", in Ensoli S. and La Rocca E. (eds.), Aurea Roma. Dalla città pagana alla città cristiana, Rome, 140-146, nos. 114-124, 491-501.

Polzer J. 1986: "A Late Antique Goddess of the Sea", JbAC 29, 71-108.

Rauch M. 1999: Bacchische Themen und Nilbilder auf Campanareliefs (Internationale Archäologie, 52), Rahden.
Ridgway B. S. 2001: Hellenistic Sculpture I. The Styles of ca. 331-200 B.C., Madison, Wisconsin.

Schwarz M. V. 1989: "Mittelalterliche Dekorationsgefüge. Eine Studie über Schauplätze und Methoden von Antikrezeption", Römisches Jahrbuch der Bibliotheca Herziana 25, 97-126.

Settis S. (ed.) 1988: La Colonna Traiana, Torino.

Shelton K. J. 1981: The Esquiline Treasure, London.

Sieger J. D. 1987: "Visual Metaphor as Theology: Leo the Great's Sermons on the Incarnation and the Arch Mosaics at S. Maria Maggiore", Gesta XXVI/2, 83-91.

Spain S. 1979: "The promised Blessing": The Iconography of the Mosaics in S. Maria Maggiore", ArtB LXI, 518-540.

Sperduti L. 1996: "La Basilica paleocristiana" in Luciani, R (ed.), Santa Maria Maggiore e Roma, Rome, 49-72.

Squarciapino M. F. 1966: Leptis Magna, Basle.

Steigerwald G. 2003: "Noch einmal zur Darstellung Jesu im Tempel am Triumphbogen von S. Maria Maggiore in Rom”, JbAC 46, 74-83.

Stout A. M. 2001: "Jewelry as a Symbol of Status in the Roman Empire", in Sebesta J. L. and Bonafante L. (eds.), The World of Roman Costume, Madison, Wisconsin, 77-100.

Stutzinger D. 1983: "Vier Silberstatuetten von Stadttychen", in Spätantike und frühes Christentum, Mainz, no. 84, 481-483.

Takács S. A. 1995: Isis and Serapis in the Roman World, Leiden-New York-Cologne.

Tammisto A. 1997: Birds in Mosaics (Acta Instituti Romani Finlandiae XVIII), Rome.

Testini P. 1963: “Osservazioni sull'iconografia del Cristo in trono fra gli apostoli", Rivista dell'Istituto Nazionale d'Archeologia e Storia dell'Arte, N. S. XI-XII, 230-300.

Tomei A. 1990 a: Iacobus Torriti Pictor. Una vicenda figurativa del tardo Duecento romano, Rome.

Tomei A. 1990 b: "La decorazione pittorica della Basilica tra duecento e trecento", in Pietrangeli C. (ed.), S. Giovanni in Laterano, Florence, 89-95.

Toynbee J. M. C. 1967, The Hadrianic School, Rome.

Verdier Ph. 1980: Le couronnement de la Vierge, Montréal-Paris.

von Stritzky M-B. 1980: "Zur Interpretation der "Darstellung im tempel" im Triumphbogen von Santa Maria Maggiore", RömQSchr 75, 133-145.

Warland R. 2002: Templum Urbis und Sibylla. Die spätantike Romidee in den Triumphbogenmosaiken von S. Maria Maggiore in Rom", Nobilis arte manus. Festschrift A. Middeldorf Kosegarten, Dresden and Kassel 2002, 25-42.

Warland R. 2003: "The Concept of Rome in Late Antiquity reflected in the mosaics of the triumphal arch of S. Maria Maggiore in Rome", ActaAArtHist XVII, $127-$ 139.

Weitzmann K. 1965: "Eine spätkomnenische Verkündigungsikone aud dem Sinai und die zweite byzantinische Welle des 12. Jh.", in Festschrift für Herbert von Einem, Berlin, 299-312. 
Weitzmann K. 1978: The Icon. Holy Images - Sixth to Fourteenth Century, New York.

Weitzmann K. (ed.) 1979: Age of Spirituality (Catalogue of the exhibition at the Metropolitan Museum of Art), New York

Wellen G. A. 1961: Theotokos, Utrecht-Antwerpen.
Wilpert J. 1916: Die römischen Mosaiken und Malereien der kirchlichen Bauten vom IV bis XIII Jahrhundert, Freiburg im Breisgau.

Wilpert J. and Schumacher W. N. 1976: Die römischen Mosaiken der kirchlichen Bauten vom IV.-XIII. Jahrhundert, Freiburg-Basel-Vienna. 